\title{
The Enhancement Difference of Student Mathematical Problem Solving Ability between Guided Discovery Learning Model and Direct Learning Model
}

\author{
Delima Simanjuntak ${ }^{1, *}$, E. Elvis Napitupulu ${ }^{1}$, Martua Manullang ${ }^{1}$, Rismalyah Manalu $^{1}$, Lamtiur Sinambela $^{2}$ \\ ${ }^{1}$ State University of Medan, Medan, Indonesia \\ ${ }^{2}$ Pelita Harapan University of Medan, Medan, Indonesia \\ *Corresponding author: delimasimanjuntak23@yahoo.co.id
}

Received October 01, 2018; Revised November 20, 2018; Accepted December 26, 2018

\begin{abstract}
The aim of this study is to analyze whether there is enhancement difference of student mathematical problem solving ability (MPSA) taught by guided discovery learning model (GDLM) and direct learning model (DLM). This study is quasi experiment study. The population of this study is seventh grade student of junior high School (SMP N 2 Kutalimbaru). The sample of this study is two classes of seventh grade of junior high School (SMP N 2 Kutalimbaru) which is taken randomly. The experiment class is taught by GDLM and the control class is taught by DLM. The result of this study shows that there is enhancement difference of student MPSA taught by GDLM and taught by DLM. N-gain of student taught by GDLM is higher than student taught by DLM.
\end{abstract}

Keywords: problem solving ability, guided discovery learning model, direct learning model

Cite This Article: Delima Simanjuntak, E. Elvis Napitupulu, Martua Manullang, Rismalyah Manalu, and Lamtiur Sinambela, "The Enhancement Difference of Student Mathematical Problem Solving Ability between Guided Discovery Learning Model And Direct Learning Model." American Journal of Educational Research, vol. 6, no. 12 (2018): 1688-1692. doi: 10.12691/education-6-12-15.

\section{Introduction}

One of the most important education in humanlife is mathematic education because everything in this world is always connected to mathematic. Mathematic is lesson which gets special attention because math is base of application in daily life which always taught in every education level. [1] Cockroft stated that math is important taught to student because: (1) Math is always used in every life aspects (2) all subject needs math skill (3) math is strong, brief, clear communication tools (4) math is used to present information in variety ways (5) it enhances logic, accuracy, spatial awareness ability and (6) it gives satisfaction towards challenging problem solving effort.

In daily life, we can not avoid problem which means that problem solving is main focus in math learning. Mathematic problem solving is the most important thing. It becomes general purpose of math learning even as the hearth of math because it prioritize the process more than the result. As focus of math, school propose to help student in developing mathematical thinking mathematically. Therefore, [2] Napitupulu said that problem solving is difficult task to be solved because it needs double skill and connect many skills for them who wants to apply in daily life. To be a good problem solver, student needs many chances to create and solve problem in math aspects and in real life context.
The importance of math education is not in line with the real math education quality. The winning of indonesian student in variety international olimpyc does not make indonesian student quality improved. According to Program for International Student Assessment (PISA) [3] which held survey under OECD (Organization Economic Cooperation and Development) authority in last 2015 about indonesian math student ability showed that Indonesia was on the $69^{\text {th }}$ rank from 76 countries. The result was released in the beginning of December 2016. Meanwhile, according to [4] TIMSS (Trends in International Mathematics and Science Study) result study showed that Indonesia was on $36^{\text {th }}$ rank from 49 countries. It shows the low quality and ability of math of Indonesian student recently.

From the pre-test given namely MPSA test shows that MPSA is on low category. The low ability of student MPSA can be caused by many things. Researchers suspect the causes of students' low mathematical problem-solving abilities, can be influenced by the learning used by the teacher so far or the teacher has not applied the learning model used in accordance with the steps. Based on the observations of researchers at junior high School (SMP Negeri 2 Kutalimbaru), during the learning process carried out, the teacher only focuses on providing knowledge and routine questions. The teacher lacks students' enthusiasm for learning, this is because the learning process carried out by the teacher in teaching only explains the concept, gives an example of the problem and continues by telling students to work on routine questions. The teacher also 
does not provide further training and application according to the steps to the four direct learning models such as giving questions in the form of problems in daily life. It is seen that fellow students are also not involved in sharing knowledge such as discussing in discussing a material or question that is considered difficult. In this case, it is necessary to study in a study whether the learning model chosen by the teacher in the school can provide good results or the results are the same if applied according to the syntax.

In the learning process there are many innovative learning models that can be used by the teacher. One of lerning model can be used to enhance problem solving ability is guided discovery learning model. [5] shows that guided discovey learning model is effective to improve student mathematical problem solving ability. Also, in [6] shows that math student understanding ability taught by guided discovery learning model is better than taught by direct learning model.

\section{Theoretical Review}

Guided discovery learning model was developed based on cognitive view about constructive learning and principle. According to [7] guided discovery is one teaching approach where the teacher gives student spesific topic example and guide student to understand the topic. In this approach, the first important thing is build student mental ability in the whole learning process or student oriented. Guided discovery is a learning approach where students find and use variety information source and ideas to enhance understanding about a problem, topic, or issue. Besides, according to [8] in guided discovery learning, students also learn problem solving and thinking skills independently because they must analyze and manipulate information. In guided discovery approach, student and teacher collaborate working together to find ideas. Students role as study community, help and study each other. Not role as individual in finishing their own task.

In problem solving not all question is a problem. A question will be a problem if only the question shows there is a unsolve challenge by known student routine procedure. [9] states that problem is unknown entity and if it is known, it will be social cultural and intellectual value. Problem solving is process which is used to solve problem. [10] states that problem solving is not only purpose in learning math but also main tool to be used in math. [11] states that math problem solving ability is ability to solve mathematical difficulties by joining obtained concept and rules before to gain the desired purpose. Problem solving ability becomes one of required developed ability in math learning. According to [12] there are three steps in problem solving namely (1) Understanding the problem (2) Planning the solution and (3) Getting an answer.

\section{Research Question}

a. Is there enhancement difference of student mathematical problem solving ability taught by guided discovery learning model and taught by direct learning model? b. Is N-gain of students mathematical problem solving ability taught by guided discovery learning model higher than taught by direct learning model?

\section{Research Method}

This study is categorized into quasi experiment study. The population of this study is the whole seventh grade student of second state junior high school (SMP N 2 Kutalimbaru). The sample of this study is VII-I as the experiment class with total student is 30 students and VII-II as the control class with total student is 30 students. The experiment class of this study will be taught by GDLM and the control class will be taught by DLM. As for the research design used in this study is the pretest-posttest control group design.

Table 1. Experimental Design

\begin{tabular}{|c|c|c|c|}
\hline Kelas & Pre Test & Treatment & Post Test \\
\hline Exsperimental & $\mathrm{T}_{1}$ & $\mathrm{X}_{1}$ & $\mathrm{~T}_{2}$ \\
\hline Control & $\mathrm{T}_{1}$ & $\mathrm{X}_{2}$ & $\mathrm{~T}_{2}$ \\
\hline
\end{tabular}

\section{Result and Discussion}

\subsection{Result}

The aim of this study is to analyze the enhancement difference of student MPSA taught by GDLM and DLM. The result of student MPSA is obtained from pre-test and post-test on experiment class and control class. The test result gives information about student ability before and after teaching and learning process either in experiment class taught by guided discovery learning or in control class taught by direct learning.

Based on Table 2 shows that pre-test and post-test probability score for each of learning model is higher namely 0.05 , it means that $\mathrm{H}_{\mathrm{o}}$ is accepted or in other words the data of student MPSA was obtained from normal distributed population.

Based on Table 3 and Table 4 shows that pre-test and post-test probability score is higher namely 0.05 . It means that the data of student MPSA was obtained from the same data group variable or homogeneity.

Table 2. Normality Test of MPSA

\begin{tabular}{|c|c|c|c|c|}
\hline \multirow{2}{*}{ Normality } & \multirow{2}{*}{ Learning Model } & \multicolumn{3}{|c|}{ Kolmogorov-Smirnov $^{\mathrm{a}}$} \\
\cline { 3 - 5 } & & Statistic & $\mathrm{df}$ & Sig. \\
\hline \multirow{2}{*}{ Pre Test } & GDLM & .114 & 30 & $.200^{*}$ \\
\cline { 2 - 5 } & DLM & .155 & 30 & .062 \\
\hline \multirow{2}{*}{ Post Test } & GDLM & .135 & 30 & .169 \\
\cline { 2 - 5 } & DLM & .150 & 30 & .083 \\
\hline
\end{tabular}

Table 3. Homogeneity Pre-Test Score MPSA

\begin{tabular}{|c|c|c|c|}
\hline $\mathrm{F}$ & $\mathrm{df1}$ & $\mathrm{df} 2$ & Sig. \\
\hline .920 & 1 & 58 & .341 \\
\hline
\end{tabular}

Table 4. Homogeneity Post-Test Score MPSA

\begin{tabular}{|c|c|c|c|}
\hline $\mathrm{F}$ & $\mathrm{df1}$ & $\mathrm{df} 2$ & Sig. \\
\hline .050 & 1 & 58 & .824 \\
\hline
\end{tabular}


Table 5. Recapitulation of N-Gain Result of MPSA

\begin{tabular}{|c|c|c|c|}
\hline \multirow{2}{*}{ Class } & Pre Test & Post Test & N-Gain \\
\cline { 2 - 4 } & $\bar{x}$ & $\bar{x}$ & $\bar{x}$ \\
\hline GDLM & 30,42 & 55,08 & 0,36 \\
\hline DLM & 27,42 & 46,33 & 0,26 \\
\hline
\end{tabular}

Based on Table 5 before treatment, the mean score of student MPSA in experiment class is 30.42 and the mean score of student MPSA in control class is 27.42. After treatment, there is means improvement score of MPSA towards both of the group. The mean of student MPSA in experiment class is $55.08(\mathrm{~N}$-gain $=0.36)$. According to Hake category [13] the enhancement of student mathematical problem solving ability taught by GDLM is categorized into medium category $(0.39 \leq 9 \leq 0.7)$. The mean of student MPSA in control class is $46.33(\mathrm{~N}$-gain $=0.26)$. According to Hake category (1998) the enhancement of student MPSA taught by DLM is categorized into low category $(9 \leq 0.3)$.

Based on Table 6 and Table 7 result test of student MPSA the regression equation for experiment class $\mathrm{Y}_{\mathrm{E}}=$ $30.290+0.815 \mathrm{X}_{\mathrm{E}}$ and the regression equation for control class is $\mathrm{Y}_{\mathrm{C}}=26.874+0.710 \mathrm{X}_{\mathrm{C}}$

From the calculation on Table 8 about problem solving ability obtained $\mathrm{F}$ calculate is 29.794 . According to $\mathrm{F}$ table, the $\mathrm{F}$ table is 4.171 . In this case, $\mathrm{F}$ calculate is higher than F table $(29.794 \geq 4.171)$ means that $H_{0}$ is rejected and $\mathrm{H}_{\mathrm{a}}$ is accepted. It means that there is positive effect (significant) of student MPSA test result (X) towards student post test result (Y) for experiment class.

From the calculation on Table 9 about problem solving ability obtained $\mathrm{F}$ calculate is 49.549 . According to $\mathrm{F}$ table, the $\mathrm{F}$ table is 4.171 . In this case, $\mathrm{F}$ calculate is higher than F table $(49.549 \geq 4.171)$ means that $\mathrm{H}_{0}$ is rejected and $\mathrm{H}_{\mathrm{a}}$ is accepted. It means that there is positive effect (significant) of student MPSA test result (X) towards student post test result (Y) for control class.

From the calculation on Table 10 about problem solving ability obtained $\mathrm{F}$ calculate is 0.849 . According to $\mathrm{F}$ table, the $\mathrm{F}$ table is 2.488 . In this case, $\mathrm{F}$ calculate is lower than $\mathrm{F}$ table $(0.849 \leq 2.488)$ means that Ho is accepted or regression model for experiment class is linear.

From the calculation on Table 11 about problem solving ability obtained $\mathrm{F}$ calculate is 0.702 . According to $\mathrm{F}$ table, the $\mathrm{F}$ table is 2.599 . In this case, $\mathrm{F}$ calculate is lower than $\mathrm{F}$ table $(0.702 \leq 2.599)$ means that $\mathrm{Ho}$ is accepted or regression model for control class is linear.

Table 6. Result of Regression Coefficiens for Experiment Class

\begin{tabular}{|l|l|c|c|c|c|c|}
\hline \multirow{2}{*}{ Model } & \multicolumn{2}{|c|}{$\begin{array}{c}\text { Unstandardized } \\
\text { Coefficients }\end{array}$} & $\begin{array}{c}\text { Standardized } \\
\text { Coefficients }\end{array}$ & \multirow{2}{*}{$\mathrm{t}$} & \multirow{2}{*}{ Sig. } \\
\cline { 3 - 6 } & $\mathrm{B}$ & Std. Error & Beta & & \\
\hline \multirow{2}{*}{1} & (Constant) & 30.290 & 5.021 & & 6.032 & .000 \\
\cline { 2 - 7 } & $\mathrm{X}$ & .815 & .149 & .718 & 5.458 & .000 \\
\hline
\end{tabular}

Table 7. Result of Regression Coefficiens for Control Class

\begin{tabular}{|l|l|c|c|c|c|c|}
\hline \multicolumn{2}{|l|}{ Model } & \multicolumn{2}{|c|}{$\begin{array}{c}\text { Unstandardized } \\
\text { Coefficients }\end{array}$} & $\begin{array}{c}\text { Standardized } \\
\text { Coefficients }\end{array}$ & \multirow{2}{*}{$\mathrm{t}$} & \multirow{2}{*}{ Sig. } \\
\cline { 3 - 6 } & $\mathrm{B}$ & Std. Error & Beta & & \\
\hline \multirow{3}{*}{1} & (Constant) & 26.874 & 3.256 & & 8.254 & .000 \\
\cline { 2 - 7 } & $\mathrm{X}$ & .710 & .101 & .799 & 7.039 & .000 \\
\hline
\end{tabular}

Table 8. Independence Test of MPSA for Experiment Class

\begin{tabular}{|l|l|c|c|c|c|c|}
\hline \multicolumn{2}{|l|}{ Model } & Sum of Squares & df & Mean Square & F & Sig. \\
\hline \multirow{3}{*}{1} & Regression & 4095.074 & 1 & 4095.074 & 29.794 & $.000^{\mathrm{a}}$ \\
\cline { 2 - 7 } & Residual & 3848.468 & 28 & 137.445 & & \\
\cline { 2 - 7 } & Total & 7943.542 & 29 & & & \\
\hline
\end{tabular}

Table 9. Independence Test of MPSA for Control Class

\begin{tabular}{|l|l|c|c|c|c|c|}
\hline \multicolumn{2}{|l|}{ Model } & Sum of Squares & df & Mean Square & F & Sig. \\
\hline \multirow{3}{*}{1} & Regression & 4398.541 & 1 & 4398.541 & 49.549 & $.000^{\mathrm{a}}$ \\
\cline { 2 - 7 } & Residual & 2485.626 & 28 & 88.772 & & \\
\cline { 2 - 7 } & Total & 6884.167 & 29 & & & \\
\hline \multicolumn{2}{|l}{ a. Predictors: (Constant), X } \\
\multicolumn{2}{|l}{ b. Dependent Variable: Y }
\end{tabular}

Table 10. Result Regression Linearity of MPSA for Experiment Class

\begin{tabular}{|c|c|c|c|c|c|c|c|}
\hline & & & Sum of Squares & $\mathrm{df}$ & Mean Square & $\mathrm{F}$ & Sig. \\
\hline \multirow{5}{*}{$\mathrm{Y} * \mathrm{X}$} & \multirow{3}{*}{ Between Groups } & (Combined) & 5726.875 & 14 & 409.063 & 2.768 & .030 \\
\hline & & Linearity & 4095.074 & 1 & 4095.074 & 27.711 & .000 \\
\hline & & Deviation from Linearity & 1631.801 & 13 & 125.523 & .849 & .612 \\
\hline & \multicolumn{2}{|l|}{ Within Groups } & 2216.667 & 15 & 147.778 & & \\
\hline & \multicolumn{2}{|l|}{ Total } & 7943.542 & 29 & & & \\
\hline
\end{tabular}

Table 11. Result Regression Linearity of MPSA for Control Class

\begin{tabular}{|c|c|c|c|c|c|c|c|}
\hline & & & Sum of Squares & $\mathrm{df}$ & Mean Square & $\mathrm{F}$ & Sig. \\
\hline \multirow{5}{*}{$\mathrm{Y} * \mathrm{X}$} & \multirow{3}{*}{ Between Groups } & (Combined) & 5600.313 & 17 & 329.430 & 3.079 & .027 \\
\hline & & Linearity & 4398.541 & 1 & 4398.541 & 41.113 & .000 \\
\hline & & Deviation from Linearity & 1201.772 & 16 & 75.111 & .702 & .750 \\
\hline & \multicolumn{2}{|l|}{ Within Groups } & 1283.854 & 12 & 106.988 & & \\
\hline & \multicolumn{2}{|l|}{ Total } & 6884.167 & 29 & & & \\
\hline
\end{tabular}


From the calcultion on Table 12 about problem solving ability obtained $\mathrm{f}$ calculate is 74.368 . According to $\mathrm{f}$ table, the $\mathrm{f}$ table is 4.007 . In this case $\mathrm{f}$ calculate is higher than $\mathrm{f}$ table $(74.368 \geq 4.007)$ means that Ho is rejected. It means that both linear regression model is different significantly.

From the calculation on Table 13 about problem solving ability obtained $\mathrm{F}$ calculate is 0.354 . According to $\mathrm{F}$ table, the $\mathrm{F}$ table is 4.001 . In this case $\mathrm{F}$ calculate is lower than $\mathrm{F}$ table $(0.354 \leq 4.001)$ means that Ho is accepted. It means that both linear regression model for control class and experiment class is linear. Both of regression model is not linear. It can be concluded that there is difference of result test for experiment class and control class.

From the calculation on Table 14 about problem solving ability obtained F calculate is 5.599 . According to $\mathrm{F}$ table, the $\mathrm{F}$ table is 4.001 . In this case, $\mathrm{F}$ calculate is higher than $\mathrm{F}$ table $(5.599 \geq 4.001)$ means that $\mathrm{H}_{0}$ is rejected and $\mathrm{H}_{\mathrm{a}}$ is accepted. It can be concluded that there is enhancement difference of student problem solving ability in applying guided discovery learning model and direct learning model.

Table 12. ANOVA for the Similarities of Two Regression Models

\begin{tabular}{|c|c|c|c|c|c|c|}
\hline \multicolumn{2}{|c|}{ Model } & Sum of Squares & $\mathrm{df}$ & Mean Square & $\mathrm{F}$ & Sig. \\
\hline \multirow{3}{*}{1} & Regression & 8975.857 & 1 & 8975.857 & 74.368 & $.000^{\mathrm{a}}$ \\
\hline & Residual & 7000.289 & 58 & 120.695 & & \\
\hline & Total & 15976.146 & 59 & & & \\
\hline \multicolumn{7}{|c|}{ a. Predictors: (Constant), X } \\
\hline \multicolumn{7}{|c|}{ b. Dependent Variable: Y } \\
\hline
\end{tabular}

Table 13. Regression Model Alignment

\begin{tabular}{|c|c|c|c|c|}
\hline Class & SST $_{x}$ & SST $_{y}$ & SPT & SST $_{x}$ (adj) \\
\hline GDLM & 6163,542 & 7943,542 & 5023,958 & 3848,468 \\
\hline DLM & 8731,042 & 6884,167 & 6197,083 & 2485,626 \\
\hline Total & 14894,583 & 14827,708 & 11221,042 & 6334,09 \\
\hline $\mathbf{A}$ & $\mathbf{B}$ & $\mathbf{F}^{*}$ & $\mathbf{F}$ & $\mathbf{H}_{\mathbf{0}}$ \\
\hline 6334,09 & 6374,180 & 0,354 & 4,001 & Accepted \\
\hline
\end{tabular}

Table 14. Result ANCOVA of MPSA

\begin{tabular}{|l|c|c|c|c|c|}
\hline Dependent Variable: PostTest_GDLM DLM \\
\hline Source & $\begin{array}{c}\text { Type III Sum } \\
\text { of Squares }\end{array}$ & df & $\begin{array}{c}\text { Mean } \\
\text { Square }\end{array}$ & F & Sig. \\
\hline Corrected Model & $9601.965^{\text {a }}$ & 2 & 4800.983 & 42.932 & .000 \\
\hline Intercept & 11490.414 & 1 & 11490.414 & 102.751 & .000 \\
\hline PreTest_GDLM DLM & 8453.528 & 1 & 8453.528 & 75.594 & .000 \\
\hline Model & 626.109 & 1 & 626.109 & 5.599 & .021 \\
\hline Error & 6374.180 & 57 & 111.828 & & \\
\hline Total & 170256.250 & 60 & & & \\
\hline Corrected Total & 15976.146 & 59 & & & \\
\hline
\end{tabular}

a. R Squared =,601 (Adjusted R Squared $=, 587$ )

\subsection{Discussion}

Based on the result study, the N-gain mean score of student MPSA taught by GDLM is 0.40 higher than taught by DLM namely 0.18 . The obtained regression model of experiment class towards problem solving ability is $\mathrm{Y}_{\mathrm{E}}=30.290+0.815 \mathrm{X}_{\mathrm{E}}$ and control class $\mathrm{Y}_{\mathrm{C}}=26.874+$ $0.710 \mathrm{X}_{\mathrm{C}}$. Then, because both of constanta of linear regression line equation of experiment class problem solving ability is 30.290 , higher than constanta of control class of linear regression line equation, 26.874. Geometrically, line regression for experiment class is on the top of control class line regression. It indicates that there is significant difference and the height of line regression shows the student result study, namely when $\mathrm{X}=0$ so the regression equation towards experiment class problem solving ability obtained $\mathrm{Y}=30.290$ and the regression equation of control class $\mathrm{Y}=26.874$. It can be concluded that there is enhancement difference of student problem solving ability in applying guided discovery learning model and direct learning model.

The result shows that the students enhancement of mathematical problem solving ability of which are taught by guided discovery learning is higher than student which are taught by direct learning. It is caused by the superiority of guided discovery learning. The applying of guided discovery learning in math learning demands the student to find the concept independently, train students' thinking ability, analyze and manipulate information. By applying this learning model, the students can find and use various information and idea source to enhance understanding about problem, topic and issue. The students are encouraged to study actively through active involvement about concepts and principles.

In guided discovery learning, the students will be involved actively in experience and reflect the experience. The students learn by building experience based on what they have known and through guidance in the learning process, the students have many ways in learning and the students learn through social interaction with others and the students learn through guidance and experience which is suitable to their cognitive development. Arends also stated that the motivated person will do action and behave in a certain way [14].

The direct learning makes the learning situation be teacher center, the teacher dominates the learning situation. The direct learning makes the teacher as learning source for the students, the teacher plays big role in transfering knowledge process to the students, the teacher explains the lessons which is being learnt, otherwise the students will listen the explanation calmly. If the students don't understand about the explanation, the students will give questions to the teacher which means the asking-answering happened. After giving explanation, the teacher will give some exercises to students about the lesson which have been explained. The activities in direct learning will make the students become passive students in learning. The students only accept, listen, then note the lessons given by the teacher. It makes the students don't truly understand the certain lesson. The lessons given only as memory for the students.

It makes big difference on students which are taught by guided discovery learning and on students which are taught by direct learning. The students which are taught by guided discovery learning will be more active in giving question, thinking and working in constucting certain knowledge. Otherwise, the students which are taught by direct learning they tend to accept and listen teacher's explanation. The teacher doesn't demand the students to be more active in thinking, discussing, and working. 
Besides, the students which are taught by direct learning only know certain knowledge and the studens which are taught by guided discovery learning will understand more and really master the knowledge. This case is the cause of students enhancement which are taught by guided discovery learning is higher than students enhancement which are taught by direct learning.

The result of study is same with [15] Achera, Belecina and Garvida study in their study about the effect of guided discovery towards students result in learning. The group which were taught by guided discovery learning is better than group which were taught by direct learning. The students which were taught by guided discovery learning positively and significantly affect students' achievement in learning. The students were more interested and motivated to learn through guided discovery learning.

\section{Conclusion}

Based on analysis result, mathematic learning either taught by guided discovery learning or direct learning can be concluded as follows:

a. There is enhancement difference of student mathematical problem solving ability taught by guided discovery learning and taught by direct learning.

b. N-gain of students mathematical problem solving ability taught by guided discovery learning model is higher than taught by direct learning model.

\section{References}

[1] Cockroft, W. H. (1982). Mathematics Counts, Report of the Commitee of Inguiry Into the Teaching of Mathematics in School. London: Her Majesty's Stationery Office.
[2] Napitupulu, E. E. (2008). Mengembangkan Strategi dan Kemampuan Siswa Memecahkan Masalah Matematik. Jurnal Pendidikan Matematika Phytagoras. 2(2): 26-36.

[3] PISA 2015. (2016). Result in Focus, What 15-year-olds knomw and whay they can do with what they know. OECD, Programme for International Student Assesment.

[4] TIMSS and PIRLS International Study Center. 2011. TIMSS 2011 Mathematics Achievement.

[5] Fitria, A.C.; Sulistyaningsih, D. \& Prihaswati, M. (2014). Keefektifan Metode Guided Discovery Learning Bernuansa Multiple Intelligences untuk Meningkatkan Kemampuan Pemecahan Masalah Matematis. JKPM. 1(2): 1-6.

[6] Pasaribu, E. Z., Surya, E. \& Syahputra, E. 2016. Peningkatan Kemampuan Pemahaman dan Disposisi Matematis Siswa Melalui Model Pembelajaran Penemuan Terbimbing di MTSN 1 Padangsidempuan. Jurnal Paradikma. 9(2): 11-19.

[7] Eggen, P. (2012). Strategi dan Model Pembelajaran Mengajar Konten dan Keterampilan Berpikir, Edisi 6. Jakarta: PT Indeks.

[8] Kuhlthau, C. C.; Maniotes, L.K. \& Caspari, A. (2007). Guided inquiry: learning in the $21^{\text {st }}$ century school, USA: Libraries Unlimited.

[9] Jonassen, D.H. (2004). Learning to Solve Problem. An instructional Design Guide. San Fransisco: John Wiley \& Son, Inc.

[10] National Council of Teachers of Mathematics. (2000). Principles and Standards for School Mathematics. NCTM: Reston VA.

[11] Hasratuddin. 2015. Mengapa Harus Belajarr Matematika? Medan: Perdana Publishing.

[12] Charles, R.; Lester, F. \& O'Daffer, P. (1987). The analytic scoring scale. How to evaluate progress in problem-solving. Reston, VA: National Council of Teachers of Mathematics.

[13] Hake, R. (1998). Relationship of Individual Student Normalized Learning Gains in Mechanics with Gender, High-School Physics, and Pretest Scores on Mathematics and Spatial Visualization. Physics Education Research Conference. Boise, Idaho.

[14] Arends, R. 2008. Learning to Teach Belajar untuk Mengajar Edisi Ketujuh/Buku Dua. Terjemahan oleh Helly Prajitno Soetjipto dan Sri Mulyantini Soetjipto. 2008. Yokyakarta: Pustaka Belajarf.

[15] Achera, L. J.; Belecina, R. R. \& Garvida, M.D. (2015). The Effect of Group Guided Discovery Approach On The performance of Students in Geometry. International Journal of Multidisciplinary Research and Modern Education (IJMRME). 1(2). 